personal experience. When I came to the university in 1971, George Demko warned me that I would soon be visited by a charming woman who would ask me to take on some additional teaching for an introductory course on the Soviet Union, in which guest lecturers would speak on their specialties. George said that she would explain in the nicest way that I would not be paid for this and that my department would give me no credit for it, but he predicted that her powers of gentle persuasion were so great that I would be helpless to resist. Jan came, and George was right. I thought of her recently when I heard someone describe a really good salesman in these words: "He could sell muzzles to dogs." Jan could sell extra work to college professors. In this way she assembled-without a budget!a stable of experts who, under her direction, taught one of the most popular undergraduate courses at Ohio State.

Jan's early efforts as Art's research assistant at Michigan State grew into coauthorship, the principal result of which was their joint study, Men versus Systems: Agriculture in the USSR, Poland, and Czechoslovakia (1971). At Ohio State, her first solo publications were journal articles and reviews, and in addition she edited or coedited books of readings from the Current Digest of the Soviet Press (then housed on the OSU campus) for use in her interdisciplinary course. In 1977 came her first individual book (an outgrowth of her dissertation) titled Citizen Inspectors in the Soviet Union: The People's Control Committee, which Jerry Hough described as "the first book ever written on an institution as important [to the Soviet political system] as the People's Control Committee." In retirement, with Art now doing payback as her research assistant, Jan wrote her most acclaimed work, A Foreign Policy in Transition: Moscow's Retreat from Central America and the Caribbean, 1885-1992 (1992), which received one of the AAASS "Oscars" for 1993, the Marshall Shulman prize for the best book on Russian or east European international relations. The accompanying citation described the book as "a conceptually elegant study of a little-researched area in Soviet foreign policy" and "an important concluding chapter" to the story of how the Soviet empire collapsed through overextension.

Jan and Art were a gifted pair of scholar-administrators with remarkably parallel professional lives. Both reached the vice-provost level of university administration, though it took Jan only fifteen years to do it. Both championed the cause of Slavic studies, though with different tactics, and it is difficult to say whether Art's tough love or Jan's gentle persuasion was more effective. Both were productive scholars in their chosen fields. Early on, Jan assisted Art in his research; later, Art assisted Jan. Each wrote a prize-winning book-Art's Bolsheviks in the Ukraine and Jan's A Foreign Policy in Transition-though the books came twenty-nine years apart. Their married lives were a fruitful, 65-year symbiosis, aptly symbolized by their nearly contemporaneous deaths.

James P. Scanlan Ohio State University January 2008

\title{
Warren Lerner, 1929-2007
}

Warren Lerner, a member of the American Association for the Advancement of Slavic Studies since its inception, died on 2 December 2007, at the age of 78 in Durham, North Carolina. He was born in Boston, Massachusetts, on 16 July 1929. Following his undergraduate education at Boston University, Warren received his MA at Columbia University's Russian Institute (now the Harriman Institute), and his doctorate in history at Columbia University where he studied under G. T. Robinson and Philip Mosley. He came to Duke University in 1961, where he joined John Curtiss and other colleagues in the history department in building one of the strongest Slavic area studies programs in the southeast. At various times Warren served as chair and director of graduate studies, and he was also a founding member of the advisory board of the Title VI National Resource Center jointly operated by the Slavic studies centers at Duke and the University of North Carolina at Chapel Hill. In 1956, he traveled to Warsaw, Moscow, Kiev, Samarkand, and Tashkent on a Ford Foundation Fellowship, making him one of the very first American scholars to have 
access to such a wide expanse of the former Soviet Union in the years before the cultural exchange program was established.

Warren's scholarly contributions include, above all, Karl Radek, the Last Internationalist (1970), which remains the definitive study of this leading Bolshevik, and his edited volume The Development of Soviet Foreign Policy: Studies in Honor of W. W. Kulski (1973), which contributed to the establishment of this field of study among historians of the Soviet Union. In recent years, Warren was at work on a large study of the Jewish community in Bialystok. He also published in fields beyond his specialization in Soviet history, best represented by his book, A History of Socialism and Communism in Modern Times: Theorists, Activists, and Humanists (1982), which has gone through three editions. As clearly evidenced in the comprehensive notes to these volumes, he had a reading knowledge of Polish, German, and Yiddish as well as Russian. In recognition of these achievements, he was awarded the senior scholar award at the annual meeting of the Southern Conference of Slavic Studies in 2004.

Warren's reputation at Duke among both his many graduate students and the literally thousands of undergraduates who filled auditorium-size classrooms to take his courses, was virtually legendary. He had the gift of precise timing in his lectures, always knowing when to interject his subtle humor into the huge array of factual material and analysis. $\mathrm{He}$ combined this with the ability to share his enthusiasm for the subject matter with his students in a way that few academics have mastered. For all of us who had the good fortune to have had personal and professional contacts with Warren over the years, his moral integrity and high professionalism will remain a standard to emulate.

Martin A. Miller

Duke University

February 2008

\section{John Doyle Klier, 1944-2007}

"I count myself a wannabe Mercurian (qualifications: ex-Catholic, ex-German-Irishethnic, ex-American from Rust Belt US) who currently resides in London teaching Jewish history - that most slippery and disputatious of slippery and disputatious 'disciplines' - to the elite sons and daughters of Mercurians who long to be British (and therefore Apollonians)." This is the ironic characterization that John Klier gave himself and his occupation in 2005.

His road to this strange and fascination occupation took the following form. John's interest in the Soviet Union (and subsequently in the history of the Russian empire) rose from such varying events as the repression of the 1956 Hungarian uprising and Iurii Gagarin's flight into space. Born in Bellefonte, Pennsylvania, on 13 December 1944, John took his BA and MA at the University of Notre Dame in Indiana and completed his doctorate in 1975 at the University of Illinois, Urbana-Champaign. His doctoral dissertation concerned the origin of the "Jewish question" in Russia. Subsequently, in answer to the traditional question of what brought him to the study of Jewish history, John would answer, "I knew I would never be bored."

John taught for many years at Fort Hays State University in Hays, Kansas, which he called a "Medvezhii ugol Ameriki" (roughly, "a god-forsaken corner of America"). But there was a bright side: as John put it, "it was easy to work there without getting distracted by anything. There was one movie theater and two TV channels. It was already possible to get the Jewish press on microfilm. I taught days, and continued my research in the evenings. I read Rassvet, Sion, Den', Voskhod."

Serious work on the history of Russia's Jews was possible only if one could gain access to Soviet libraries and archives. But the topic of Jews was absolutely a "no go" for scientific exchanges with the USSR. John had to think of a topic that, on the one hand, allowed him access to exactly those materials he needed, and, on the other hand, was free of the adjective Jewish: the topic he chose was the Russian press. In a period of extreme suspicion toward foreigners, he was able to spend two years in Leningrad (1977-78 and 